\title{
Thymic basaloid carcinoma: a rare clinical entity
}

\author{
Sukesh Manthri, ${ }^{1}$ Haroon H Rehman, ${ }^{1}$ Patrick N Costello, ${ }^{2}$ Kanishka Chakraborty ${ }^{1}$
}

'Division of Hematology/ Oncology, Department of Internal Medicine, East Tennessee State University, Johnson City, Tennessee, USA ${ }^{2}$ Watauga Pathology, East Tennessee State University, Johnson City, Tennessee, USA

\section{Correspondence to}

Dr Kanishka Chakraborty; chakrabk@etsu.edu

Accepted 19 November 2019

\section{DESCRIPTION}

Primary thymic carcinoma is a rare malignancy and particularly basaloid type is an even rare subtype, with less than 20 cases published as individual case reports in the English literature. ${ }^{1-5}$ A 61-year-old female patient presented after falling, with concern for rib fracture. CT of abdomen/pelvis with contrast to evaluate for splenic injury revealed two left hepatic lobe masses with the largest measuring $5.1 \mathrm{~cm}$ concerning for metastatic disease. Positron emission tomography (PET) showed anterior mediastinal mass measuring $6.5 \times 3.8 \mathrm{~cm}$ with standardized uptake value (SUV) 8.9 and two enlarged hypermetabolic liver masses. Ultrasound-guided liver biopsy showed a pleomorphic cell population not morphologically consistent with the liver primary (figure 1). Immunohistochemical stains were diffusely positive for pan-cytokeratin, GATA3, CD117, P63, CD5 and showed scattered positive cells for CK7. The neoplasm was negative for CK 20, SatB2, ER, PR, GCDFP-15, mammaglobin, TTF-1, Hep Par 1, synaptophysin, chromogranin and CK 5/6. Coexpression of CD 117 and CD5 is typical of thymic carcinoma (figures 2 and 3 ). The histological features and the immunohistochemical staining pattern were consistent with metastatic basaloid-type thymic carcinoma. The patient was subsequently started on carboplatin area under the curve (AUC) 5 and Taxol $200 \mathrm{mg} / \mathrm{m}^{2}$. The patient is currently status post 11 cycles of chemotherapy and interim scans showed response to treatment. Thymic carcinomas are rare aggressive tumours with poorer prognosis and higher mortality than thymomas as they often metastasize to regional lymph nodes and extrathoracic sites. Given the rarity of this malignancy, chemotherapy options are extrapolated from phase II studies. Carboplatin/paclitaxel is the preferred

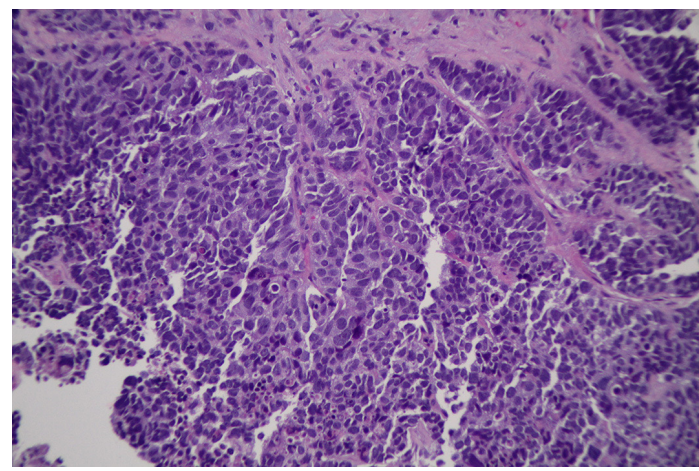

Figure 1 Liver biopsy showing pleomorphic cell population.

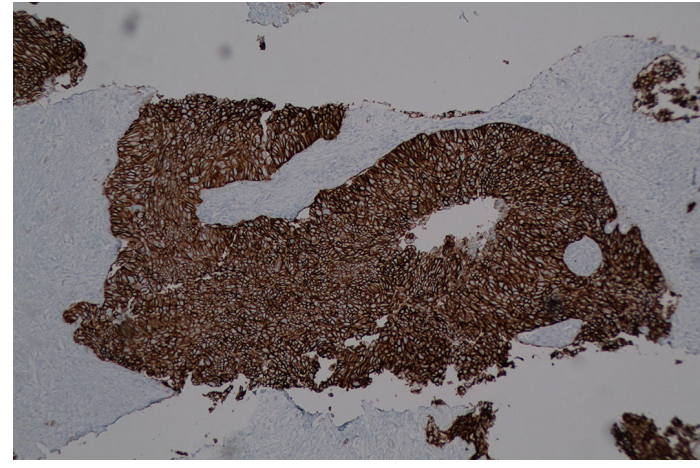

Figure 2 Immunohistochemical stain highlighting diffuse positivity for CD5.

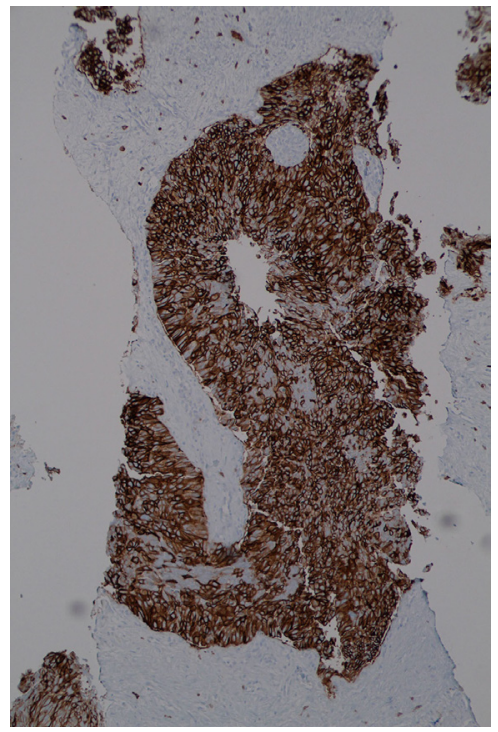

Figure 3 Immunohistochemical stain highlighting diffuse positivity for CD117.

Learning points

Basaloid type of thymic carcinoma is a rare malignancy with less than 20 cases published in the literature.

- Coexpression of CD117 and CD5 on immunohistochemistry is typical of thymic carcinoma.

- Thymic carcinomas do have a poorer prognosis and higher mortality than thymomas as they often metastasize to regional lymph nodes and extrathoracic sites.

first-line therapy with an overall response rate, $22 \%-36 \%{ }^{7}$ Further long-term follow-up and examination of additional cases are needed to 
understand exact pathophysiology and assess response to additional chemotherapy.

Contributors SM and HHR worked on the abstract, PNC provided with a pathological description along with images, and KC revised and edited the abstract.

Funding The authors have not declared a specific grant for this research from any funding agency in the public, commercial or not-for-profit sectors.

Competing interests None declared.

Patient consent for publication Obtained.

Provenance and peer review Not commissioned; externally peer reviewed.

\section{REFERENCES}

1 Matsuo T, Hayashida R, Kobayashi K, et al. Thymic basaloid carcinoma with hepatic metastasis. Ann Thorac Surg 2002;74:579-82.
2 Posligua L, Ylagan L. Fine-Needle aspiration cytology of thymic basaloid carcinoma: case studies and review of the literature. Diagn Cytopathol 2006;34:358-66.

3 Brown JG, Familiari U, Papotti M, et al. Thymic basaloid carcinoma: a clinicopathologic study of 12 cases, with a general discussion of basaloid carcinoma and its relationship with adenoid cystic carcinoma. Am J Surg Pathol 2009;33:1113-24.

4 Sakakura N, Tateyama H, Usami N, et al. Thymic basaloid carcinoma with pleural dissemination that developed after a curative resection: report of a case. Surg Today 2010:40:1073-8.

5 Suemitsu R, Takeo S, Momosaki S, et al. Thymic basaloid carcinoma with aggressive invasion of the lung and pericardium: report of a case. Surg Today 2011;41:986-8.

6 Huang J, Rizk NP, Travis WD, et al. Comparison of patterns of relapse in thymic carcinoma and thymoma. J Thorac Cardiovasc Surg 2009;138:26-31.

7 Lemma GL, Lee J-W, Aisner SC, et al. Phase II study of carboplatin and paclitaxel in advanced thymoma and thymic carcinoma. J Clin Oncol 2011;29:2060-5.

Copyright 2019 BMJ Publishing Group. All rights reserved. For permission to reuse any of this content visit

https://www.bmj.com/company/products-services/rights-and-licensing/permissions/

BMJ Case Report Fellows may re-use this article for personal use and teaching without any further permission.

Become a Fellow of BMJ Case Reports today and you can:

- Submit as many cases as you like

- Enjoy fast sympathetic peer review and rapid publication of accepted articles

- Access all the published articles

Re-use any of the published material for personal use and teaching without further permission

\section{Customer Service}

If you have any further queries about your subscription, please contact our customer services team on +44 (0) 2071111105 or via email at support@bmj.com.

Visit casereports.bmj.com for more articles like this and to become a Fellow 